\title{
The Great War and the Middle East
}

\author{
Rob Johnson \\ Oxford: Oxford University Press, 2016. 354 pages.
}

This book attempts to provide a new reading of the historical events that served to shape the Middle East, during and immediately after the first Great War (1914-1918). While it does not go so far as to make revisionist claims, it does make a claim to an alternative perspective on other narratives. The author questions how this grand conflict has been portrayed, not only in its immediate aftermath but also in its long-term effects observed in current regional instabilities.

The book includes twelve chapters arranged chronologically and by region, focusing on the military conflicts of WWI not as a study of "military history of maneuvers" as such, but as a "study of war" in a fashion that reflects the interactions of decision-makers involved in this great conflict (x). The first chapter introduces the reader to the "making of imperial strategy" focusing on "ends and ways" (1). By the early twentieth century, Britain appeared to face numerous threats from other great powers such as Germany, 
France, and Russia, and a relative decline in its naval power, the mainstay of empire $(2,21-22)$. Thus, Britain sought to set its strategy and to protect its interests through four means: diplomacy, spheres of interest, buffer states, and military and naval interventions (2-3). British decision-makers designed these policies to serve the strategic purposes of preserving national interests, upholding values, and preserving the security, wealth, prestige, stability, influence, and political culture of the empire (19). They also sought to economize on having large standing armies or land forces (14) and to cultivate loyal native elements and social classes (13). Propping up the faltering Ottoman Empire as a buffer against Russian expansionism and as a means of stalling possible cooperation with Germany (should war erupt) was also an example of a policy aspect in practice $(26,28,269)$.

Chapter 2 extends the analysis of the previous chapter beyond ends and ways, to "ways and means". On the eve of the war in 1914, the Ottoman Empire had sought to reorganize and modernize its army as a way of preserving its own integrity. The British army, in contrast, constituted of a small volunteer force, was a means well suited for expeditionary warfare against small states but inadequate for large-scale continental wars against great powers such as Germany $(35,39)$. When the war broke out, British War Minister Lord Horatio Kitchener perceived that on the western front Germany was too powerful to be defeated. He adopted the view that it would be more practical to give priority to knocking out its weaker ally on the eastern front (48). Commander of British forces in the west, Sir John French, and despite all the difficulties on that front, made the point to Kitchener that "the Eastern theater of war is one in which a success on the part of the Allies would have the most decisive results. On the other hand a great German success in the West would be fatal" (90). The overall strategic view was that defeating the Ottoman empire would set in motion a dynamic that would bring other Central Powers to the negotiating table with or without Germany, which could then be isolated and defeated (59).

In order to achieve this "masterstroke", the British high command pursued two interlinked sub-strategies. The first was to provide for adequate defense against any possible Ottoman counter-attacks aimed at the Suez Canal or the invasion of Egypt, and against the German strategy of fomenting revolutions among Muslims (chap. 3; 74ff). The second was to strike at the Ottoman heartland in the Dardanelles at Gallipoli (1915; chap. 4). The first strategy seemed to work and the Suez Canal remained secure; however, the second proved a debacle, even if ultimately it did not alter the outcome of the war. 
The following four chapters of the book chronologically cover the other battles in Sinai and Palestine (1915-16; chap. 5), the Mesopotamia Campaign (1914-1916; chap. 6), the battles of the Caucasus and Sarikamush (1915-16; chap. 7), and the Arab Revolt in the Hejaz and Palestine (1916-17; chap. 8). Finally, the last four chapters cover how strategy was methodically implemented in Mesopotamia (1917-18) (chap. 9), the way the Ottoman Empire was defeated (1918, chap. 10), strategies of negotiation after the war and peacemaking (1919-23; chap. 11), and finally the making of strategy in war and peace (chap. 12).

The thematic aspect of the entire study-where it comes from and attempts to head-does reflect a measure of bias. Johnson attempts to deflect Western responsibility, particularly that of Britain, away from being the cause of much of the conflicts that have "plagued" the Arab World and the region ever since (vii) in favor of a "strategic" approach that restores this missing dimension of the Great War in the Middle East (ix). To serve the former purpose, the author challenges the view that the decision-makers of 1914-19 were acting according to a predetermined master plan. To serve the latter purpose, he suggests that those leaders were in fact simply trying to win a war and to make sense of what may come after it, without necessarily anticipating subsequent unintended consequences (vii). In other words, how things developed were not the outcome of a visionary strategy, but of an emergent one in which victorious powers did not have a predrawn design, but were simply driven by the force of circumstances, for much of which local actors were to blame. As Johnson put it rather ironically, "[e] ven the champion of Arab nationalism, T.E. Lawrence, was disillusioned by the lack of any prospect of Arab unity" (viii), striking at the same time an equivalent ironic note regarding Kaiser Wilhelm II being the champion of Islamic jihad (74-75). Even the Sykes-Picot agreement (viii) and the Balfour Declaration (229-230) are presented as disconnected events simply expressing "vague" ideas and understandings related to post-war "areas of territorial responsibility" (i.e. mandates) (viii). Nothing, that is, was really being planned nor envisioned.

Attempting to recover the strategic dimension of the Great War in the Middle East and concentrating on the higher level of war, rather than on tactics and operations, as Johnson states the purpose of his study to be, should have yielded less perplexity in this regard, even if at this higher level of abstraction. Within the strategic framework of "ends, ways, and means" that he points to early in his book (vii), emergent strategies simply reflect the ways through which a visionary masterplan or ends are pursued, putting 
the existing extensive means at the service of such ends, with the purpose of maximizing goals to be achieved (ends) while minimizing costs of achievement (means). The devised mandate system for example, could very well be seen as a way (emergent strategy) of reconciling means (instrumental resources) and ends (visionary strategy), toward 'intended consequences' (redrawing the map of the region). Accordingly, visionary and emergent strategies stand in a complementary relationship along a continuum, rather than as alternatives.

This framework provided for the dynamic structure within which subsequent developments took place. The study's premise that Great Britain was simply reacting to local "agency" (or perhaps more accurately, manipulating local agents), trying to adapt decisions it made and to respond accordingly, together with the "central idea" that it was all about "prevailing concepts, context, and changing conditions" (emergent strategies, ways) tends to reflect part of the whole story. For that matter, the part obfuscates the whole (visionary strategy, ends) (viii). As Johnson put it, "[t]he assumption that Westerners are the cause of the region's troubles is a refrain, frequently articulated, but rarely substantiated" $(\mathrm{x})$. He does point out nevertheless that the "notion of 'self-determination' and the rights of small nations produced a direct contradiction of Britain's plans for federations across the Middle East" (xi). This sounds like Britain did have a plan after all, had it not been for the League of Nations' (i.e. American president Woodrow Wilson's) ill-advised interventions that spoiled everything.

Mystification involves shifting the blame back and forth among several actors. Such attempts at mystification are not totally new and have been part of a historical policy discourse that aims at justifying or exonerating Britain from the tragic events that followed, particularly as related to the usurpation of Palestine but also as related to colonial takeovers. The study nevertheless is interesting in a number of respects. It illustrates a continuation of a narrative that seeks to navigate British responsibility away from much of what is currently occurring in the Middle East, despite a continuous British policy since then, for example, in support of the Zionist construct of Israel. The study also underscores the important strategic insight that, despite claims about the events taking place in the east being a sideshow, entente victory on the western front was achieved there after all. 